anthropology and engineering sections respectively. An exhibition illustrating this central topic of the meeting is being organised, and a series of five public lectures on its various aspects will be given in Birmingham by distinguished speakers.

The sectional meetings will be held at Edgbaston (within the city and about three miles from its centre), in the University, King Edward's Schools and the Teachers' Training College.

At a British Association meeting, one is always torn between conflicting attractions, and the same difficulty is met in choosing subjects for mention from among the sectional programmes. A somewhat random selection on the side of the physical sciences includes "Heat Flow in the Earth's Crust" (Section A), "Chemistry of Plastics, Rubbers and Fibres" (Section B), and "Automatic Control Systems" (Section G). On the biological side, interest in Section D will centre on entomological questions, while in Section $\mathrm{K}$ the president's theme of modern trends in classification will be elaborated by a discussion of its cytogenetical aspects in which Section $\mathrm{D}$ will also join. Section $\mathrm{K}^{*}$ (Forestry) will also spend an afternoon discussing the genetical aspects of forestry problems. At first thought, agriculture may seem little related to Birmingham, yet the city is, in fact, the centre of an area with diverse agricultural problems. The surrounding counties are among the best agricultural areas in Great Britain. In the Evesham district there flourishes a special combination of market gardening and agriculture, while even the Black Country has its own problem, that of rehabilitating derelict areas. All these will be reflected in Section M's programme, and Section G is taking up the specially appropriate topic of agricultural engineering. The presidential address to Section $H$, on "The Influence of the Potato on Social Structure", will appeal to a wide biological and agricultural, as well as anthropological, audience. Section B will discuss with Section I the chemistry of muscular contraction, and with Section $K$ the chemistry of the cell and nucleus; while the great attraction of Section $\mathrm{L}$ will be an address by Dr. J. B. Conant, president of Harvard University, on "An Experiment in the Study of Science by Non-scientists".

The Evening Discourses will be given by Prof. $\mathrm{K}$. von Frisch on "The Language of the Bees", by the Bishop of Birmingham (Dr. E. W. Barnes, F.R.S.) on "Science, Religion and Moral Judgment", and by Dr. A. C. B. Lovell on "The New Science of Radio Astronomy".

On Sunday, September 3, the preacher at a special service in St. Martin's Church will be the Very Rev. W. R. Matthews, Dean of St. Paul's. Representatives of the Free Churches will take part in this service.

Excursions for scientific purposes, and for pure pleasure, have long been traditional at British Association moetings. This year's programme is as full and varied as usual, ranging from factories within sight of the meeting-rooms to the source of Birming ham's famous Welsh water in the Elan Valley. Social occasions will include receptions given by the City and the University, and a garden party given by Messrs.* Cadbury, Ltd.

A list is given below of the presidents of Sections and chairmen of Sub-Sections, with the titles of the addresses they will read. Further information about the meeting may be obtained from the Secretary of the British Association, Burlington House, Piccadilly, London, W.1, or from the Local Secretaries for the meeting at the Council House, Birmingham, 1 .
(A) Mathematics and Physics: Prof. E. H. Neville: Mathematical Notation.

(B) Chemistry : Prof. E. L. Hirst: Modern Developments in Carbohydrate Chemistry.

(C) Geology : Dr. W. Campbell Smith: Stony Meteorites.

(D) Zoology: Dr. V. B. Wigglesworth: The Science and Practice of Entomology.

(E) Geography : Prof. S. W. Wooldridge: The Upland Plains of Britain; their Origin and Gec. graphical Significance.

(F) Economics: Prof. G. C. Allen : Economic Progress : Retrospect and Prospect.

(G) Engineering : Prof. Andrew Robertson: A Chapter in Bridge Engineering a Century Ago.

(H) Anthropology and Archæology : Dr. R. N. Salaman: The Influence of the Potato on Social Structure.

(I) Physiology : Prof. R. J. Brocklehurst : Hormones of the Digestive Tract.

(J) Psychology : Dr. J. C. Flugel : Human Affairs and the Psychological Point of View.

(K) Botany : Dr. W. B. Turrill : Modern Trends in the Classification of Plants.

$\left(\mathrm{K}^{*}\right)$ Forestry : The Right Hon. Lord Bolton : Some Post-war Forestry Problems.

(L) Education: W. F. Oalkeshott : Education and Power.

(M) Agriculture: Prof. H. D. Kay : Quality in Agriculture.

\section{THE SPANISH HIGHER COUNCIL FOR SCIENTIFIC RESEARCH}

TUMEROUS representatives recently attended a most interesting and successful meeting in Madrid to celebrate the tenth anniversary of the founding of the Higher Council for Scientific Research. In recent years in all countries, government interest in the development of research facilities has been greatly extended, and various mechanisms for rendering such development possible have been put into operation. One of the most interesting of these is the Spanish experiment, the outcome of which will be well worth watching. Both in the United States and in Great Britain, continuous effort must be exercised to prevent dichotomy arising between governmentsponsored research and university research. Again, the development of research on the arts side proceeds in these countries independently and without any contact with scientific progress. The concept of a 'Higher Council' on which the universities, royal academies, national defence research departments, as well as the schools of mining, of engineering, of fine arts, of sacred and political science are represented is both novel and intriguing in its possibilities.

The Council groups the various branches of science into three sections : physical, biological and spiritual subjects. Each section is composed of two trusts, and the trusts are responsible for the research institutes, museums and sections. There are now more than fifty institutes for which the Council is responsible. These are by no means all situated in Madrid, as it is the policy of the Higher Council to decentralize its activities so far as possible. Thus, for example, the Institute of Parasitology is in Granada, that of church history in Salamanca, of applied chemistry in Saragossa, and in Jaca is the Pyrenean Studies Centre. 
Naturally, the main administration buildings, central and specialist libraries, the press and many working laboratories and institutes are in Madrid itself, comprising a remarkable blơck of modern wellconstructed and expensively furnished buildings. Like the Department of Scientific and Industrial Research in Great Britain, the Higher Council provides funds for research to those who have graduated from a university, and annual prizes are given for outstanding work both in letters and in science. It is also the function of the Higher Council to advise the Minister of Education as to the award of any special prizes or life pensions for outstandingly meritorious work. One of Europe's most interesting of modern churches is the Church of the Holy Ghost, built by the Higher Council for Scientific Research in the Council Enclosure, to provide a spiritual home for all research workers, both Spanish and foreign. The Council also provides chapels in the neighbouring buildings, so that all teachers and students can make use of these during their working period.

Another interesting phase of the Higher Council's activities is to be found in the School of Ancillary Studies, in which a large staff is trained in such a way that "without entering deeply into theories, by means of a careful and practical apprenticeship they may become valuable helpers for scientific workers". British universities are in great need of the services of really skilled technicians such as glass-blowers, fine mechanics and experts in electronic circuits. It is no easy matter to obtain such valuable members of the scientific staff; and the steps which the Higher Council has taken in respect to this matter are well worth serious attention.

The foreword to the law founding the Higher Council expresses most clearly the intentions and ideas that led to its conception. "The state of divorce and discordance existing between speculative and experimental science must be terminated and the tree of science must be encouraged to develop harmoniously as a whole by avoiding the monstrous growth of some branches while others wither and die. A strong counter-weight must be found for the exaggerated and isolated specialization so prevalent in our time and the sciences must be made to regain their old sociability." A noble experiment : may it succeed.

Eric K. Rideal

\section{OBITUARIES}

\section{Dr. H. R. Mill}

Hugh Robert MILL, distinguished geographer, meteorologist and author, died at Dormans Park, East Grinstead, on April 5, at the age of eighty-eight. He had an outstanding personality. He devoted his life mainly to the study of geography, especially of those aspects dealing with ocernography, the study of lakes, the flow of rivers, the Antarctic and rainfall. Born at Thurso, Caithness, in 1861, he became doctor of science of the University of Edinburgh, honorary doctor of laws of St. Andrews, fellow of the Royal Society of Edinburgh, honorary member of the Institution of Water Engineers and fellow or honorary member of a large number of British and foreign scientific societies.

After specializing in chemistry and physics at the University of Edinburgh, Mill became chemist and physicist in 1884 to the newly established Scottish Marine Station at Granton on the Firth of Forth.
This work renewed an early interest in geography, and he was appointed lecturer in physiography in the Heriot Watt College, Edinburgh. In 1891 he published a standard text-book on geography, introducing a more systematic and scientific treatment, with the attractive title "The Realm of Nature".

From 1892 until 1900 he was librarian to the Royal Geographical Society, where he found time to make the first systematic survey of the depths of English lakes. He became recorder of Section E (Geography) of the British Association (1893-99) and president in 1901, and attained an international reputation as a geographer. On the occasion of the Society's centen. ary he prepared, at the request of the Council, "The Record of the Royal Geographical Society, 1830 1930". In 1915 he received the Victoria Research Medal of the Society and was vice-president during 1927-31.

In 1901 Dr. Mill, to quote his own words, seized a proffered opportunity "to devote the rest of my working life to one small portion of the great problem of my earlier dreams : the detailed investigations of the control of rainfall distribution by the forms of the land". He became director of the British Rainfall Organization at 62 Camden Square, London, and editor of "British Rainfall" and Symons's Meteorological Magazine, until he retired in 1919, when the Organization was incorporated in the Meteorological Office. In 1910 he presented the whole of the accumulated rainfall records and property of the British Rainfall Organisation, acquired at his own expense, to be held in trust for the nation. During this period he applied his geographical knowledge and his experience to open up new lines of research, especially in map studies of rainfall, thereby advancing the scientific study of the rainfall distributions over Great Britain. He became the authority on British rainfall and was consulted by government departments and other bodies. He was honorary secretary of the Royal Meteorological Society during 1902-6 and president in 1907-8. The Society awarded him the Symons Memorial Medal in 1918 and the newly instituted Hugh Robert Mill Medal and Prize for research in rainfall just before his death.

Although widely travelled, Mill had never entered Antarctic regions. Throughout his life, however, he maintained personal friendships with the explorers and acquired an expert knowledge of Antarctic exploration. He wrote "The Siege of the South Pole" in 1905 and "The Life of Sir Ernest Shackleton" in 1923. Illustrative of his relationships with these explorers is a telegram to Dr. Mill from Shackleton in September 1916 from Punta Arenas on his return from the far South : "My grateful thanks for friendly article about expedition and for your consistent belief in me your friend Shackleton".

Both in his lectures and writings, Mill had a happy and fascinating manner of presenting and interpreting facts. He was a source of inspiration to many in the various spheres of work which occupied his full life. In spite of eyesight already failing in 1915, he maintained throughout his life a hopeful outlook and lively interest in all aspects of "the Realm of Nature".

J. Glasspoone

\section{Mr. J. B. Scrivenor, I.S.O.}

JOHN BROOKE ScRIvenor, the first geologist to start systematic geological mapping in Malaya, died peacefully in his sleep at his home in Bedford on April 21, at the age of seventy-three. 